\title{
Retention Strategies in the Leading ITeS Organizations of Delhi NCR
}

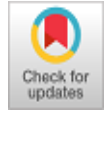

\author{
Shivanjali, Mitushi Singh, Tripti Singh, J.K. Sharma
}

\begin{abstract}
The IT sector in India is at times having a lot of trouble in providing technical services to the organizations spread across the country. The task is more challenging due to the scarcity of competent engineers in comparison to the number of organizations. A lot of the professionals prefer to serve overseas instead of serving in India. There are a lot of factors that affect the employee retention in the IT sector. The objective of this paper is to study the factors such as Promotion, compensation, conditions of works of the employees, and the type of work that has an effect on the job satisfaction of the employees and that are the causes of reduced employee retention in the IT companies in India. The sample size consists of 200 IT professionals working in different IT companies in Delhi NCR. Out of total 240 Questionnaires distributed to the employees 200 questionnaires were received and were further they have been used for the purpose analysis. For doing the data analysis/results the SPSS 20.0 and SPSS AMOS 23 has been used.
\end{abstract}

Key words: Employee retention, job satisfaction, IT sector, Engineers.

\section{INTRODUCTION}

In an organization the Human Resource plays a very key role in retention of the employees. It has been challenging for the organizations to be a contestant in the present times of intra industry competition without a highly competent employee base in an organization. All of the faithful staff is an organization are the cause of growth of an organization. It has become a task for the managers of the HR department to maintain long-term staff and minimize the organization's turnover. The reduced retention of the employees in an organization brings a hike in the cost of recruitment and selection of the new workforce and also decreases the productivity. By maintaining skilled, efficient and faithful workforce, an organisation can achieve the competitive advantage. The retention of employees is also regarded the contribution to improve the organization's economic efficiency (Raikes, 2004). The end result of the organization's enhanced turnover rate is also a result of indirect costs such as reliance on the current workers, lack of human resources, and reduced employee morale. (Shaw \& Des 2000). The reduction in employee retention increases the cost of investment and also brings a decrease in the level of working capacity and efficiency of the workers in a company. Therefore, it becomes important for the

\footnotetext{
Revised Manuscript Received on February 05, 2020.

* Correspondence Author

Shivanjali*, Amity University, Noida, India.

Dr. Mitushi Singh, Amity University, Noida, India.

Dr. Tripti Singh, MNNIT, India.

Prof. Dr. JK Sharma, Amity University, Noida, India.
}

(C) The Authors. Published by Blue Eyes Intelligence Engineering and Sciences Publication (BEIESP). This is an open access article under the CC BY-NC-ND license (http://creativecommons.org/licenses/by-nc-nd/4.0/) researchers to study the determinants that have an effect on the retention of the employees in an organization. For having the benefit of a company a competent employee base has become very important. In the current scenario, employees are thought as very valuable resources which has some major effect on the organizational performance. In IT sector, engineers are very important and valuable resources and have a very important role for achieving the technical objectives to provide max technological facilities to the organization. Human assets also require a proper management just like other assets. An emerging issue in India is that there are a number of organizations in the IT sector but only a few are able to reach benchmark expectations of its employees. On the other hand, there are a lot of people who need work but are not competent enough or they have very high demands. The job satisfaction of the employee has become very important to the organizations for retaining its loyal employees for an extended period. The primary goal of this research is to examine elements such as Promotion, compensation, Nature of work, and quality of work have a major impact on the degree of employment fulfilment.

\section{LITERATURE REVIREW}

This section explains the factors effecting employee retention in the IT companies.

\section{Effects of Compensation and Rewards on Job satisfaction \& Employee Retention}

The specialists have considered the managers of the private sector organizations to discover the factors that have an effect on the employee satisfaction at workplace and it has been inferred that employee satisfaction at the job is altogether influenced in the association by compensation practices (Sokoeya 2001). Opkaara (2002) in his investigation he found a few factors that have an impact on the degree of occupational satisfaction among the workers. Those factors are remuneration, opportunities for promotion, the kind of work to be done, associations among the collaborators and also the kind of supervision. Out of all remuneration was determined as the most predominant variable in determining fulfilment of any person at work.

In an investigation as directed by a specialist Fryee (2003) where it has been inferred that pay has been most significant determinant for the companies in order to have a strong association with the employee and furthermore charge the people for a more extended timeframe. Notwithstanding that the compensation in an association is decidedly related with the fulfilment of an employee in the organization. 
Another examination was led that concluded about a signification relationship between occupation satisfaction of the employees and pay (Nguyen et al. 2003)

In a study it has been found that the cause of the reduced employee retention is the lower level of compensation (Abassi and Hollman 2000). The research also found that there is a adverse effect on employee retention in an organisation due to inappropriate hiring, poor working conditions, less pay. (Milman 2002). In addition, job satisfaction improves with greater salary

and fringe benefits and reduces employee turnover.

\section{Effects of Promotion on Job satisfaction \& Employee Retention}

There is a significant relationship of occupational satisfaction which was investigated by researchers with statistic determinants, with also including other factors such as job autonomy, authority conduct and also the system of promotion in an organization. It has been concluded in the study that variables essentially influence the job fulfilment of workers (Daawson, 1987). Moreover Taylor \& Braadley (2003) have additionally concluded that fulfilment or organizational satisfaction of a worker is directly affected by the presence of the promotional and growth opportunities in any particular organization.

For a company to hold its loyal employee for a significant time period, an organization needs to do some investment for the professional success of all of its employees (Hall and Moss, 1998; Hssu, Jiaang, Klein \& Tang, 2002; Woodrue, 1999). The primary reason for the highly competent workforce to leave any company is due to the unavailability of promotion and training opportunities. Because of the increasing number of the turnover rate, the career growth of the employees working in such organizations is diminished. (Shoree \& Grifeth, 2002). The companies want their workforce to take the competitive advantage and their leaders need to create and help then in building up their profession along with their overall development (Prince, 2004).

\section{Effects of Working Conditions on Job satisfaction \& Employee Retention}

Hyter studied and concluded that an organization is very much looked by the outsiders with regards to industrial environmental factors. These qualities of any workplace have been found to be diverse in terms of the administration segment in comparison to the industrial segment as its task is to deal with the customers (Norman 1987).

A workplace is viewed as the most important determinant of employment fulfilment. (Specitor 2008). Another analyst in his investigation has concluded that workplace is additionally a prevalent indicator of the work fulfilment of an employee in the organizational setting (Reiner and Zhao, 1999; Carlaan, 2006; Elickson and Loggsdon, 2002; Forsyth and Copees, 1994).

Salary packages, work environment, incentives, recognition and fringe benefits of employees are some of the factors due to which differences exists (Lavy, 2007). In the past examinations the researchers have found that there are a number of variables that have been very important in retaining the loyal and competent employees in the

organization. These variables are work life balance, place of work and the opportunities for growth in the organization.

\section{Effect of Quality of work on Job satisfaction and Employee Retention}

Quality of work is another significant determinant of retention of the employees in the organization. It has been seen that focus on this was expanded owing to a rise in the country's educational level. Before that, due to low level of consciousness, education, much attention was not paid to it. In their research, have scientists discovered that the job had effect employee retention and the degree of satisfaction of the employees in an organizational setting. Ting \& Locke; 1995 concluded a significant relationship between retention of the employees and their satisfaction at the workplace. Robbins, 2003 refers to quality of work as "the degree to which the job offers stimulating tasks, learning opportunities and personal growth to the individual, and also gives their employees an opportunity to become more responsible and also be accountable for the results at work." They are most fascinated by the job related to the skills of the staff. (Robbins,1993). In a study by Koh and Goh 1995 on clerical staff in a different sector, it has been discovered that the employee retention has an adverse correlation with the Quality of the job.

\section{Effect of Job satisfaction and Employee Retention}

Employee retention as studied and researched by most of the researchers is to find its connection with the satisfaction of employees at the workplace. A very adverse connection among job satisfaction and employee turnover was discovered in the past research among most scientists. (Cotton \& Tutle, 1985; Arnold \& Feildman, 1982; etc).

A very important determinant in the delivery of standardized products and services and eventually in a company's achievement is work satisfaction (Silva, 2006). Researchers have discovered that the satisfaction of the employees at workplace important in terms of the reduced turnover and absenteeism. (Lee \& Liu, 2007).

\section{RESEARCH FRAMEWORK}

On the basis of the above review of literature, following theoretical model has been developed.

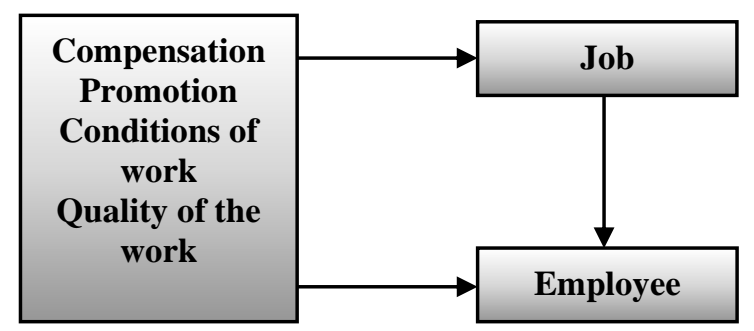

\section{HYPOTHESIS OF THE STUDY}

The following hypothesis have been stated by the researcher for the purpose of the study have stated on the basis of above studied literature: 


\section{Hypothesis 1}

$\mathrm{H}_{0}$ : Compensation does not possess a significant relation with the retention of employees.

\section{Hypothesis 2}

$\mathrm{H}_{0}$ : Promotion does not possess a significant relation with the retention of employees.

\section{Hypothesis 3}

$\mathrm{H}_{0}$ : The conditions of work does not possess a significant relation with the retention of employees.

\section{Hypothesis 4}

$\mathrm{H}_{0}$ : The Quality of work does not possess a significant relation with the retention of employees.

\section{Hypothesis 5}

$\mathrm{H}_{0}$ : Job Satisfaction Compensation does not possess a significant relation with the retention of employees.

\section{RESEARCH METHODOLOGY}

Research design: The research design used for the purpose of the study is descriptive in nature and it has been used by the researcher to ensure that the data collected for the purpose of the study is reliable.

Research instrument: For the purpose of data collection structured questionnaires have been used.

Sampling method: Nonprobability - Convenience sampling Sample size: The questionnaire developed by the researcher has 7 constructs that are compensation, promotion, Quality of work, conditions of works, job satisfaction, employee retention and demographics. These constructs have been decided after conducting review of literature of 58 papers extracted from different databases. The questionnaire was given to 200 IT professionals working in different IT companies in Delhi NCR.

Sample unit: Employees working in IT Industry companies in Delhi NCR.

\section{SOURCES OF DATA}

Primary data: The employees working in the IT sector employees have been selected for the purpose of the data collection. The value of Cronbach's alpha has been calculated as 0.910 on the basis of the pilot testing. The calculated value of Cronbach's alpha falls under the acceptable value. The data was collected by sending the questionnaire to the employees via email. The sections in the questionnaire were namely compensation, promotion, conditions of works, Quality of work, job satisfaction as the mediating variable and employee retention as the dependent variable. In the questionnaire a five point likert scale has been been used anchored by $1=$ strongly disagree and $5=$ strongly agree. The scale determined the degree of the agreement or disagreement of the respondents. There is also a section in the questionnaire having demographic and general information of the employees.

Secondary data: Research paper, books and the information available over the internet has been used for the research work.

\section{DATA ANALYSIS TOOLS AND TECHNIQUES}

The researcher has used standard statistical package namely IBM SPSS 20 and SPSS AMOS 23 for doing the data analysis.

\section{RESULTS AND FINDINGS}

\section{Response rate}

In the IT organizations of Delhi NCR 240 questionnaires were given to the possible respondents and 200 were received back by the researcher. $83.33 \%$ response rate was achieved from the target sampling unit.

\section{Respondent Demographics}

The information regarding demographics of respondents has been broadly quoted in the below given table.

\begin{tabular}{|c|c|c|c|}
\hline \multicolumn{2}{|c|}{ Description } & Frequency & Percentage \\
\hline \multirow{4}{*}{ Age } & $18-24$ & 11 & 5.5 \\
\cline { 2 - 4 } & $25-31$ & 64 & 32 \\
\cline { 2 - 4 } & $32-38$ & 45 & 22.5 \\
\cline { 2 - 4 } & $39-45$ & 35 & 17.5 \\
\cline { 2 - 4 } & $46-52$ & 29 & 14.5 \\
\cline { 2 - 4 } & More than 52 & 16 & 8 \\
\hline \multirow{3}{*}{ Gender } & Male & 129 & 64.5 \\
\cline { 2 - 4 } & Female & 82 & 35.5 \\
\hline \multirow{2}{*}{ Qualification } & Graduation & 118 & 41 \\
\hline Work tenure & Post-Graduation & 68 & 59 \\
\hline \multirow{2}{*}{ Wos } & $1-5$ years & 34 \\
\hline
\end{tabular}


Retention Strategies in the Leading ITeS Organizations of Delhi NCR

\begin{tabular}{|c|c|c|c|} 
& 6-10 years & 51 & 25.5 \\
\cline { 2 - 4 } & $11-15$ years & 25 & 12.5 \\
\cline { 2 - 4 } & $16-20$ years & 19 & 9.5 \\
\hline \multirow{3}{*}{ Quality of employment } & Above 20 years & 39 & 19.5 \\
\cline { 2 - 4 } & Contract & 18 & 9 \\
\hline
\end{tabular}

The demographics construct analysis of the questionnaire permanent basis therefore, $91 \%$ respondents among the comprises of different categories of the respondents that have been included in the demographic section of the study. As per data in above given table most of the respondents are from the age group of $25-31$ years (32\%) followed by $32-$ 38 years $(22.5 \%)$. The lowest number of respondents are from the age group of $18-24$ years (5.5\%). The respondents in this age group is less as the minimum age to work in the organization is above 18 years and most of the organization require atleast graduate employees. Even in the data table above most of the employees working these IT companies have post graduation degree (59\%).

It can be notes from the data that there are still less number of female employees (35.5) in the companies as compared to the male employee (64.5) which might be for various reasons, but the number is less.

An employee's intention to leave an organization is higher among those employees who have less tenure than the employees who have higher work period in an organization. A very high number of respondents is having a work tenure of 1-5 years (68\%) followed by 6-10 years (51\%). The least number of employees are having work tenure of $16-20$ sample collected are permanent employees only 9\% employees are working on a contractual basis.

The researcher has taken job satisfaction as the mediation factor in the study and the method adopted for the research is the method of Baron \& Keny (1986) and Judd \& Kenny (1981). For purpose of data analysis three equations have been used. The independent variables depicted in the proposed model are Promotion, Compensation, Conditions of work and Quality of Work have been regressed the mediation variable which has been taken as the mediation variable in the very first equation. In the second equation, the regression of all the independent variables on the dependent variable has been executed. The independent variables and the mediating variable have also been regressed on the dependent variable which is employee retention, in the third equation. In order to test that job satisfaction that is acting as the mediating variable and is significant with the Promotion, Compensation, Quality of the Work, Conditions of works, and the Employee Retention in the IT Sector organizations in Delhi NCR, regression analysis has been performed the equation one, two \& three.

years $(9.5 \%)$.

The maximum number of employees working in the IT companies have been recruited in the organization on

\section{EQUATION 1}

\begin{tabular}{|c|c|c|c|c|c|c|}
\hline \multicolumn{7}{|c|}{ Regression Analysis of Exogenous variable on mediation variable } \\
\hline Equation & Mediation Variable & Exogenous Variable & Beta & T & R square & F \\
\hline 1.1 & Job Satisfaction & Compensation & 0.261 & 4.637 & 0.074 & 14.243 \\
\hline 1.2 & Job Satisfaction & Promotion of employees & 0.239 & 3.434 & 0.059 & 11.729 \\
\hline 1.3 & Job Satisfaction & Conditions of work & 0.291 & 4.442 & 0.086 & 18.862 \\
\hline 1.4 & Job Satisfaction & Quality of Work & 0.253 & 3.536 & 0.061 & 12.541 \\
\hline
\end{tabular}

EQUATION 2

\begin{tabular}{|c|c|c|c|c|c|c|}
\hline \multicolumn{7}{|c|}{ Regression Analysis of Exogenous variable on Endogenous variable } \\
\hline Equation & Endogenous Variable & Exogenous Variable & Beta & T & R square & F \\
\hline 2.1 & Employee Retention & Compensation & -0.025 & -0.375 & 0.002 & 0.141 \\
\hline 2.2 & Employee Retention & Promotion & -0.113 & -1.578 & 0.015 & 2.471 \\
\hline 2.3 & Employee Retention & Conditions of work & -0.149 & -2.089 & 0.026 & 4.367 \\
\hline 2.4 & Employee Retention & Quality of Work & -0.219 & -3.092 & 0.049 & 9.57 \\
\hline
\end{tabular}

For understanding the effect of independent variables on the mediating variable the regression analysis has been executed of the first equation and has been brought to use and it has found that all of the exogenous variables possess an effect on the satisfaction level of the employees at the workplace.
Retrieval Number: C5543029320/2020@BEIESP DOI: 10.35940/ijeat.C5543.029320 Journal Website: www.ijeat.org
Published By:

2578 Blue Eyes Intelligence Engineering \& Sciences Publication 
Compensation and conditions of working in the organization has a strong effect on the satisfaction level of the employees at the workplace. Only in certain cases the effect has not been very strong but a positive relationship has been found between both these variables in rest of the cases.Further, the results of the regression analysis of the independent variables on all of the dependent variables of Employee Retention were also significantly positive as determined in the second equation of the data analysis. A relationship again exists between both the variables. The Quality of work has a major impact followed by the conditions of works of the employees. It is not only the compensation that effects the job as stated by a few literatures but the other factors also have an effect on the employee retention. Though the effect again is not very high but it is still having a significant effect on employee retention.

\section{EQUATION 3}

\begin{tabular}{|c|c|c|c|c|c|c|}
\hline \multicolumn{6}{|c|}{ Regression Analysis of Exogenous variable and mediation variable on Endogenous variable } \\
\hline Equation & $\begin{array}{c}\text { Endogenous } \\
\text { Variable }\end{array}$ & $\begin{array}{c}\text { Exogenous \& } \\
\text { mediation } \\
\text { Variable }\end{array}$ & Beta & $\mathbf{T}$ & R square & F \\
\hline 3.1 & Employee Retention & Compensation & -0.111 & -1.37 & 0.006 & 0.491 \\
\hline 3.2 & $\begin{array}{c}\text { Job } \\
\text { Satisfaction }\end{array}$ & -0.069 & -0.908 & & \\
\hline & Employee Retention & Promotion & -0.106 & -1.378 & 0.016 & 1.427 \\
\hline 3.3 & $\begin{array}{c}\text { Job } \\
\text { Satisfaction }\end{array}$ & -0.049 & -0.625 & & \\
\hline 3.4 & Employee Retention & $\begin{array}{c}\text { Conditions of } \\
\text { work }\end{array}$ & -0.139 & -1.879 & 0.024 & 2.264 \\
\hline & $\begin{array}{c}\text { Job } \\
\text { Satisfaction }\end{array}$ & -0.035 & -0.401 & & \\
\hline & $\begin{array}{c}\text { Quality of } \\
\text { Work }\end{array}$ & -0.216 & -2.934 & 0.048 & 4.791 \\
\hline
\end{tabular}

Finally, in the 3rd equation, the relationship of job satisfaction and also the independent variables with Employee retention was also tested and it was observed that the job satisfaction has been acting as the mediation variable. The beta value of compensation has been calculated as .261 in the equation 1.1 and has gradually reduced in the second equation with -.025 and 3.1 with 0.111 . The findings of the equations indicated that the mediating variable in such cases has been job satisfaction and also it can be stated that if the satisfaction level of an employee reduced with time at the workplace then the rate of employee retention gradually decreases.

\section{HYPOTHESIS RESULTS}

\section{Hypothesis 1}

$\mathrm{H}_{0}$ : Compensation does not possess a significant relation with the retention of employees.

On the basis of the literature review and the data analysis the alternate hypothesis is accepted.

\section{Hypothesis 2}

H0: Promotion does not possess a significant relation with the retention of employees.

On the basis of the literature review and the data analysis the alternate hypothesis is accepted.

\section{Hypothesis 3}

H0: The conditions of works does not possess a significant relation with the retention of employees.

On the basis of the literature review and the data analysis the alternate hypothesis is accepted.

\section{Hypothesis 4}

H0: The Quality of work does not possess a significant relation with the retention of employees.

On the basis of the literature review and the data analysis the alternate hypothesis is accepted.

\section{Hypothesis 5}

H0: Job Satisfaction does not possess a significant relation with the retention of employees.

On the basis of the literature review and the data analysis the alternate hypothesis is accepted.

\section{CONCLUSION AND RECOMMENDATIONS}

The said research related to the staff of the IT Department of IT sector organizations of Delhi NCR so as to identify the factors influencing the satisfaction level of the employees and the also effect of an employee's job satisfaction on the rate of employee retention. According to the results of the research it can be indicated that factors such as Compensation at workplace, Promotion of the employees, Conditions of works and Work Quality have been found to be the most significant for the satisfaction of the employees at work. The management of these organizations may take suitable measures to improve employees ' level of job satisfaction. In addition, management is recommended to take into account variables such as compensation, promotion, conditions of works and Quality of work to help increase employee retention in these organizations. 


\section{LIMITATIONS OF THE STUDY}

We performed the research in this study by taking Compensation, Promotion, Conditions of works and Work Quality variables. The other variables may also be used for more specific results in future studies. There was also a limited sample size that can be extended to identify other determinants as well. A comparative survey of government and private sector IT organizations may also be performed in the future.

\section{REFERENCES}

1. Arnold, H.J. and Feldman, D.C., A multivariate analysis of the determinants of job turnover, Journal of Applied Psychology, 67(3), pp. 350-360.

2. Baron, R. M., \& Kenny, D. A., The moderator-mediator variable distinction in social psychological research:

3. Conceptual, strategic and statistical considerations, Journal of Personality and Social Psychology, 51, pp. 1173-1182.

4. Bolt, J.F., Job security: its time has come, Harvard Business Review, Vol. 61, No. 6, pp. 115-23.

5. Bluedorn, A.C., A unified model of turnover from organizations, Human Relations, 35(2), pp. 135-153.

6. Borstorff, P. C., \& Marker, M.B. (2007), Turnover Drivers and Retention Factors Affecting Hourly Workers: What is Important? Management Review: An International Journal, 2(1), pp. 14-27.

7. Government Review, Vol. 33, No. 3, pp. 173-84. Forsyth, C. J. and Copes, J. H., Determinants of job satisfaction among police officers, International Review of Modern Sociology, Vol. 24, No. 1, pp. 109-16.

8. Frye, M. B. (2004), Equity-based compensation for employees: firm performance and determinants, The Journal of Fi- nancial Research, 27(1), pp. 31-54.

9. Okpara, J. O. (2004), Personal characteristics as predictors of job satisfaction; An exploratory study of IT managers in a developing economy, Information technology and people, 17 (3), pp. 327-338.

10. Smith, P.C., Kendall, L.M. and Hulin, C.L., The Measurement of Satisfaction in Work and Retirement: A Strategy for the Study of Attitudes, Rand McNally, Oxford.

11. Spector, P. (2008), Industrial and Organizational Psychology: Research and Practice, 5th ed., John Wiley \& Sons, New York, NY. 